Copyright (C) 2020 University of Bucharest Printed in Romania. All rights reserved

ISSN print: $1224-5984$

ISSN online: $2248-3942$
Rom Biotechnol Lett. 2020; 25(1): 1236-1245

doi: $10.25083 / \mathrm{rbl} / 25.1 / 1236.1245$

Accepted, July, 5, 2018

Original paper

\title{
First Report of using Response Surface Methodology for the Biodegradation of Single Azo Disperse Dyes by Indigenous Daedalea dickinsii-IEBL-2
}

\author{
RAJA TAHIR MAHMOOD ${ }^{*}$, M. JAVAID ASAD ${ }^{2}$, M. ASGHER ${ }^{3}$, SAQIB \\ HUSSAIN HADRI ${ }^{3}$, M. GULFRAZ ${ }^{2}$, J.H. DAVID WU ${ }^{5}$, MUHAMMAD ISMAIL \\ BHATTI $^{6}$, NASIB ZAMAN ${ }^{7}$, and DAWOOD AHMED ${ }^{8}$ \\ ${ }^{1}$ Department of Biotechnology, Mirpur University of Science and Technology (MUST), Mirpur- \\ 10250 (AJK), Pakistan \\ ${ }^{2}$ University Institute of Biochemistry and Biotechnology, PMAS-Arid Agriculture University \\ Rawalpindi, Pakistan \\ ${ }^{3}$ Department of Biochemistry, University of Agriculture Faisalabad, Pakistan \\ ${ }^{4}$ Department of Biochemistry and Molecular Biology, University of Gujrat, Pakistan \\ ${ }^{5}$ Department of Chemical Engineering, University of Rochester, NY, USA \\ ${ }^{6}$ Department of Plant Pathology, Sindh Agriculture University, Campus Umerkot Sindh, Pakistan \\ ${ }^{7}$ Center for Biotechnology and Microbiology, University of Swat, KP, Pakistan \\ ${ }^{8}$ Department of Medical Laboratory Technology, University of Haripur, KP, Pakistan
}

\begin{abstract}
Textile dyes accounts for $22 \%$ of total dyes utilization and are potential pollutants due to their toxicity and carcinogenicity. Brown Rot Fungi (BRF) have great potential of biodegradation of dyestuffs due to their efficient nonspecific ligninolytic enzyme system. Current study was conducted for application of indigenous Daedalea dickinsii IEBL-2, a brown rot fungi, to degrade single azo disperse dyes i.e. disperse violet-63 and disperse orange-30. Response Surface Methodology (RSM) with Box Behnken Design was employed to optimized biodegradation process. Ligninolytic enzymes involved in biodegradation were also studied and biodegradation process was monitored by High Performance Liquid Chromatography (HPLC). There was $72.14 \pm 1.1 \%$ and $68.71 \pm 1.04 \%$ biodegradation observed after screening experiments for dye- 1 and dye-2. Optimization by RSM at step- 1 increases biodegradation to $80.83 \pm 1.35 \%$ and $78.3 \pm 1.16 \%$ and after step $-2,88.93 \pm 1.32 \%$ and $93.32 \pm 1.54 \%$ respectively. Study of ligninolytic enzymes i.e manganese peroxidase, lignin peroxidase and laccase revealed their involvement in biodegradation process. HPLC analysis confirmed the biodegradation process and conversion of complex dyes into simple secondary amines i.e diphenylamine and 3-methyldiphenylamine. These findings would help to reduce the environmental pollution by textile effluent and also reduces the risk of certain diseases.
\end{abstract}

Keywords Textile dyes, response surface methodology, ligninolytic enzymes, Daedalea dickinsii, biodegradation.

To cite this article: MAHMOOD RT, ASAD MJ, ASGHER M, HADRI SH, GULFRAZ M, DAVID WU JH, BHATTI MI, ZAMAN AN, AHMED D. First Report of using Response Surface Methodology for the Biodegradation of Single Azo Disperse Dyes by Indigenous Daedalea dickinsii-IEBL-2. Rom Biotechnol Lett. 2020; 25(1): 1236-1245. DOI: 10.25083/rb1/25.1/1236.1245 


\section{Introduction}

Environmental pollution creates many problems including different threatening diseases. Reduction in environmental pollution is a great challenge for human being and it is main focus of the scientists. Textile industrial effluent is one of the major causes of environmental pollution and textile dyes are more difficult to treat due to their stability being synthetic [1-3].

Water is one of the major necessities of life for plants, animals and human being. Exposure of human body to polluted water for long period of time, lead to certain diseases like cancer. Conventional wastewater treatment processes are often ineffective in dyes removal from the effluent [1]. Conventional techniques like, ozonation, electrolysis and coagulation are often costly, limited applicability and produce more toxic secondary amines $[4,5]$.

Bioremediation is becoming important, because it is cost-effective and environmentally friendly and produces less sludge [1]. Many microorganisms are capable of decolorizing the azo dyes, including gram-positive bacteria, gram-negative bacteria and fungi. The possibility to use ligninolytic fungi for the removal of synthetic dyes is one approach that attracts considerable attention [6].

Brown rot fungi are efficient in biodegradation of recalcitrant compounds like xenobiotics, lignin and dyestuffs by their extra cellular ligninolytic enzyme system [7]. The objectives of the current study was utilization of Daedalea dickinsii IEBL-2 for the biodegradation of disperse dyes. Optimization of biodegradation and study of effect of different parameters by using RSM. Study of lignolytic enzymes secreted by fungi during biodegradation and their characterization to make them more applicable for industrial processes. Conformation of biodegradation of complex dyes by HPLC of treated and untreated sample.

\section{Materials and Methods}

\section{Source of Daedalea dickinsii IEBL-2}

Daedalea dickinsii-IEBL-2 was obtained from Industrial and Environment Biotechnology Laboratory (IEBL), Department of Biochemistry, PMAS-Arid Agriculture University Rawalpindi. Previously it was collected from Islamabad Pakistan, cultured on Malt Extract Agar media, identified morphologically from Department of Plant Pathology, PMAS-AAUR and preserved in IEB Laboratory for future use [8].

\section{Disperse dyes for biodegradation experiments}

Single azo disperse dyes i.e. disperse violet-63 (Violet $\mathrm{S}_{3} \mathrm{RL}$ ) and disperse orange-30 (Yellow brown $\mathrm{S}_{2} \mathrm{RFL}$ ) were purchased from supplier and used for biodegradation experiments. These dyes have molecular weight 414.85 and 450.27 while $\lambda \max 448 \mathrm{~nm}$ and $612 \mathrm{~nm}$ respectively.

\section{Screening of biodegradation of disperse dyes}

Biodegradation potential of $D$. dickinsii IEBL-2 for both single azo disperse dyes, the screening experiment were performed for 10 consecutive days at pre-optimized conditions $\left(\mathrm{pH} 5.5\right.$, temperature $28^{\circ} \mathrm{C}$, dye conc. $0.02 \%$, fungal inoculum $2 \mathrm{~mL}$ ).

\section{Optimization of biodegradation}

Response Surface Methodology (RSM) was used for the optimization of various parameters as well as biodegradation process. RSM is a collection statistical and mathematical tools that use to designed experiments where there is one dependent variable and many independent variables [8]. The experimental design through RSM reduces the number of treatments and time for complete optimization of all parameters [9]. Box Bhenken Design (BBD) was used to optimize 5 parameters simultaneously and studies their effect on biodegradation [10]. Following parameters were optimized and their effect was monitored to enhance the biodegradation of disperse dyes.

\section{Optimization of growth and nutritional parameters}

Growth of $D$. dickinsii IEBL-2 dependent on different parameters like $\mathrm{pH}$ of media [11], temperature and size of inoculum [12]. Two additional carbon sources glucose and fructose were optimized along with three nitrogen sources including ammonium sulfate, ammonium nitrate and ammonia [13]. Various concentrations $(0.01 \%-0.05 \%)$ were added in biodegradation mixture to monitor its effect on biodegradation [14].

\section{Study of ligninolytic enzymes}

To study the enzymes involved in biodegradation of disperse dyes, ligninolytic enzymes including lignin peroxidase (LiP), manganese peroxidase (MnP) and laccase were studied. Lignin peroxidase activity was calculated by method of Tein and Kirk 1984 [15] while manganese peroxidase activity was calculated according to method as described by WARSHII et al, 1992 [16]. Laccase activity was measured according to procedure of WOLFEDEN and WILSON, 1982 [17].

\section{Purification of enzymes}

Ligninolytic enzymes were partially purified by ammonium sulfate precipitation and gel filtration chromatography. Varying concentrations of ammonium sulfate (20-70\%) were added in crude extract and place for overnight and pellet was used for enzymes assays [18]. Gel filtration chromatography was performed with sephadex G-100 column packed with sodium phosphate buffer, elutions collected after passing $2 \mathrm{ml}$ of crude extract and subjected to enzymatic assays [19].

\section{Characterization of enzymes}

Partially purified LiP, MnP and Laccase were characterized for the most suitable $\mathrm{pH}$ of each enzyme and the most suitable temperature. For optimum $\mathrm{pH}$ enzymatic activities were performed from $\mathrm{pH}$ 4-6.5 and for optimum temperature $20^{\circ} \mathrm{C}-40^{\circ} \mathrm{C}$ [2]. Effect of varying concentration of substrate $(2 \mathrm{mM}$ to $10 \mathrm{mM})$ was also monitored to find $\mathrm{Km}$ and $\mathrm{Vmax}$ of each of the enzymes. Well characterized enzymes are more suitable for different industrial applications [19].

\section{HPLC analysis of biodegraded dyestuff}

Textile dyes usually convert into secondary amines after biodegradation by lignolytic enzymes. To confirm the biodegradation of dyes under study, biodegraded material was subjected to HPLC analysis before and after treatment. 
The peaks obtained were compared with peaks of available standards of secondary amines [20]. The HPLC was performed on SHIMAZDU LC-20AT model having C-18 column of $25 \mathrm{~mm}$ length with internal diameter of $4.6 \mathrm{~mm}$. The analysis was performed in isocratic and reverse phase mode at $1 \mathrm{~mL} / \mathrm{min}$ flow rate. The solvent system was acetonitrile: water $(60: 40)$ ratio and $20 \mu \mathrm{L}$ of each sample was injected for analysis.

\section{Results and Discussion}

\section{Screening of biodegradation potential of $D$. dickinsii IEBL-2}

Both dyes (Fig. 1a \& 1b) were screened for the biodegradation potential by $D$. dickinsii IEBL-2. The screening conditions for each experiment were $90 \mathrm{~mL}$ dye solution $(0.02 \%), 10 \mathrm{~mL}$ of liquid media, $2 \mathrm{ml}$ fungal inoculum, $\mathrm{pH} 5.5$, temperature $28^{\circ} \mathrm{C}$ and $150 \mathrm{rpm}[2,8]$. There was $72.14 \pm 1.1 \%$ biodegradation achieved for D-1 and $68.71 \pm 1.04 \%$ for D-2 after 10 days (Fig. 2). The increase is prominent up to day 7 than very low rise in biodegradation possibly due to accumulation of toxic waste and depletion of media [2, 21]. During screening LiP observed the most active enzymes with maximum activity $865.5 \mathrm{U} / \mathrm{mL} / \mathrm{min}$ followed by $\mathrm{MnP}(612.31 \mathrm{U} / \mathrm{mL} / \mathrm{min})$ and laccase (312.71 U/mL/min) (Fig. 3). Previous studies also reported the role of these enzyme in textile dyes biodegradation. Decrease in degradation after day 7 might be related with decrease in production of enzymes [22].
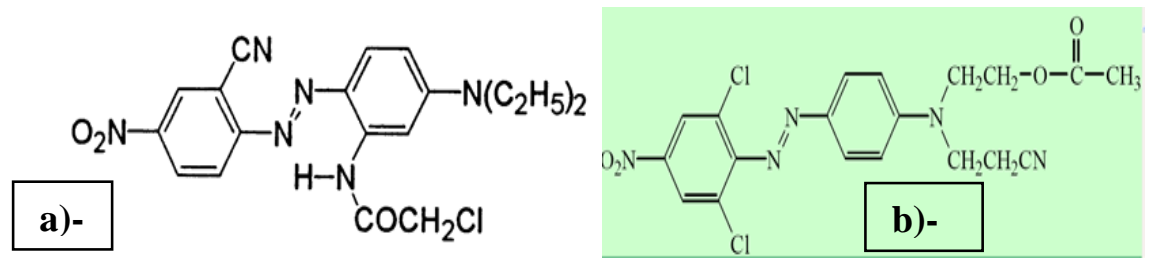

Figure 1. Structure of single azo disperse dyes (a)- disperse violet 63 (b)- disperse orange 30.

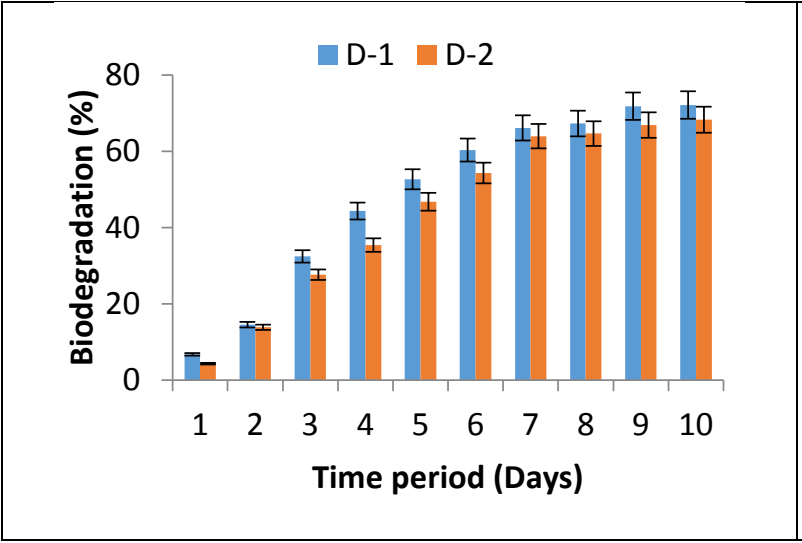

Figure 2. Screening of biodegradation of single azo disperse dyes by D.dickinsii IEBL-2.

\section{Optimization of biodegradation of disperse violet 63}

There was $9 \%$ increased in biodegradation observed after optimizing $\mathrm{pH}$, temperature, time period, inoculum size and dye conc. through RSM. Response surface graphs (3D) showed that different parameters interact positively with each other and increased biodegradation by enhancing fungal growth. Considering the interaction between $\mathrm{pH}$ of biodegradation mixture and size of fungal inoculum, there was maximum biodegradation i.e. $78.67 \%$ at $\mathrm{pH} 5.2$ and $6.89 \mathrm{~mL}$ (Fig. 4a). The side lines indicate the individual effect of change in $\mathrm{pH}$ and change in inoculum size on biodegradation. Up rise in graph indicate the positive interaction between these parameters which increase the biodegradation. If consider $\mathrm{pH}$ and temperature for their effect on biodegradation, the maximum biodegradation

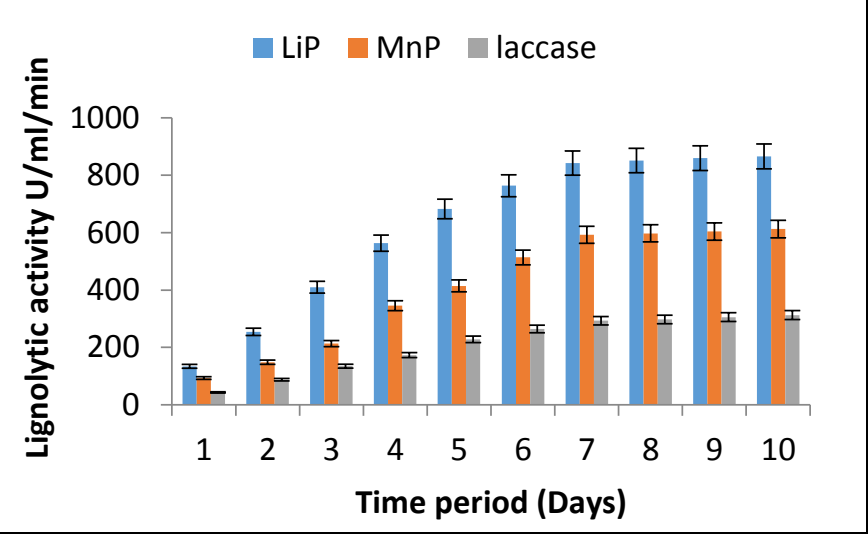

Figure 3. Activities of lignolytic enzymes produced by D. dickinsii IEBL-2 during screening experiments.

(79.49\%) observed at $\mathrm{pH} 5.36$ and $28.75^{\circ} \mathrm{C}$ with positive interaction (Fig. 4b). Similarly, very prominent interaction was observed between time period (days) and inoculum size, at $7.2 \mathrm{~mL}$ and 7.8 days there was $80.12 \%$ biodegradation observed (Fig. 4c). Same positive effect was present between dye conc. and inoculum (Fig. 4d) and also between dye conc. and temperature (Fig. 4e). When all 5 parameters collectively, maximum biodegradation $80.83 \pm 1.35 \%$ obtained at $\mathrm{pH} 5.25$, inoculum size $7.12 \mathrm{~mL}$, time period 8 days, temperature $26.59^{\circ} \mathrm{C}$ and dye conc. $0.046 \%$. There was significant effect of these parameters on biodegradation indicated by high F. ratio (22.26) and $\mathrm{P}<0.0001$ at $\mathrm{R}^{2}=95.23 \%$ (Fig. $4 \mathrm{f}$ ). There must be selection of right values of these parameters to achieve maximum biodegradation [23. 24]. 

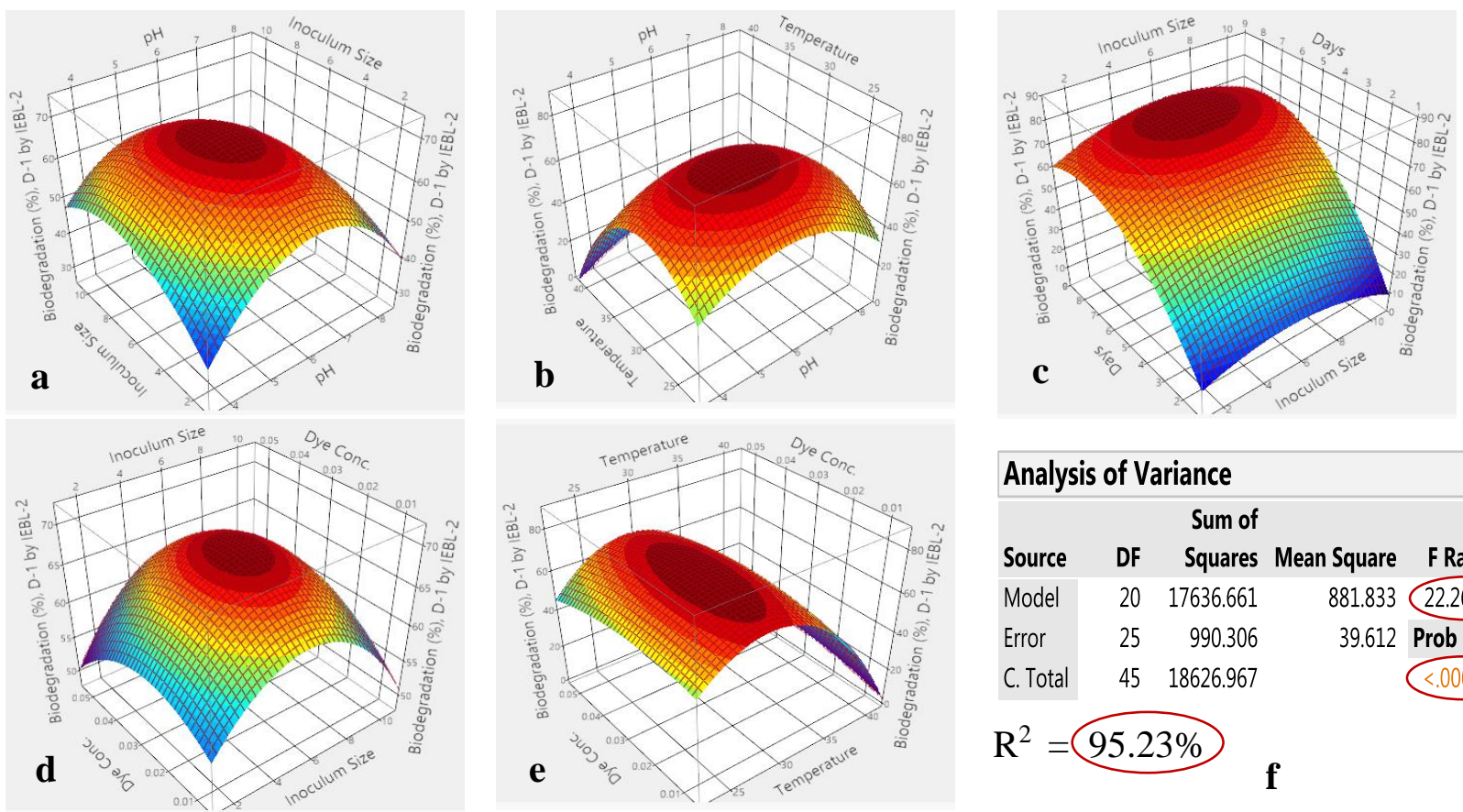

\begin{tabular}{|lrrrr|}
\hline \multicolumn{5}{|c|}{ Analysis of Variance } \\
\hline \multicolumn{5}{c}{ Sum of } \\
Source & DF & Squares & Mean Square & F Ratio \\
\hline Model & 20 & 17636.661 & 881.833 & 22.2616 \\
\hline Error & 25 & 990.306 & 39.612 & Prob > F \\
C. Total & 45 & 18626.967 & & $<.0001^{*}$ \\
\hline
\end{tabular}

$\mathrm{R}^{2}=95.23 \%$

Figure 4. Response surface 3D graphs showing interaction between parameters during the biodegradation of disperse violet 63 dye (D-1) by D. dickinsii IEBL-2, graphs represents positive interaction between (a) inoculum size and $\mathrm{pH}(\mathbf{b})$ temperature and $\mathrm{pH}(\mathbf{c})$ days and inoculum size (d)- dye conc. and inoculum size (e)- dye conc. and temperature (f)- statistical analysis of results showing significant effect of parameters on biodegradation.

Effects of five carbon and nitrogen sources were check simultaneously. There was $8 \%$ increased in biodegradation of disperse violet 63 dye by $D$. dickinsii IEBL-2. Various parameters interact positively and nearly $1 \%$ concentration of each of glucose, fructose, ammonium sulfate, ammonium nitrate and ammonia were found the most suitable for biodegradation (Fig. 5). Furthermore, concentration of ammonia more than $1 \%$ has negative effect possibly due to denaturing effect on proteins. There are many studies report the positive impact of above mentioned sources on growth of fungi and biodegradation of textile dyes by these fungi $[24,25]$.
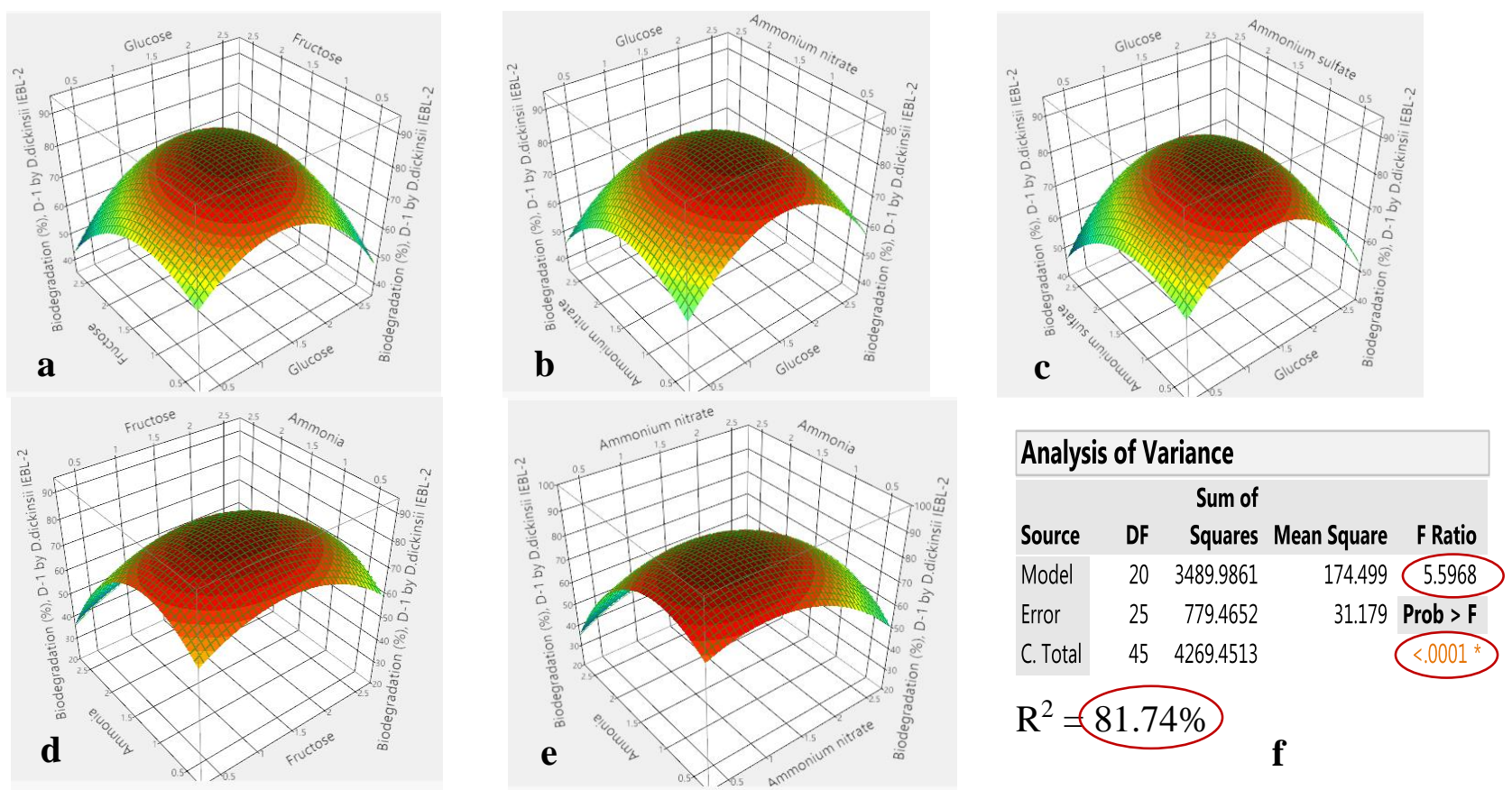

$\mathrm{R}^{2}=81.74 \%$

Figure 5. Response surface graphs showing interaction between carbon and nitrogen sources during the biodegradation of D-1 by D. dickinsii IEBL-2, graphs represents positive interaction between (a) glucose and fructose (b) glucose and ammonium nitrate (c) glucose and ammonium sulfate (d) fructose and ammonia (e)- ammonium nitrate and ammonia (f)- statistical analysis of results showing significant effect of parameters on biodegradation. 


\section{Optimization of biodegradation of disperse orange 30}

The biodegradation of disperse dye-2 was also optimized by treating with $D$. dickinsii IEBL-2 and there was $10 \%$ increase in biodegradation achieved after optimization $(78.3 \pm 1.16 \%)$ comparing with screening results $(68.71 \pm 1.04 \%)$. The study of 3D response surface graphs showed that there was positive interaction between different parameters which lead to maximum biodegradation (Fig. 6). The maximum achieved biodegradation $\%$ age was the combined effect of these parameters rather than individual affect $[2,5,19]$. The most suitable conditions observed for maximum biodegradation were $\mathrm{pH} 5.32$, inoculum size $6.78 \mathrm{~mL}$, time period 8 days, temperature $27.11^{\circ} \mathrm{C}$ and dye conc. $0.04 \%$. The statistical analysis of the results indicated high $\mathrm{F}$. ratio (21.43), very low $P$ value $(P=<0.0001)$ and high $R^{2}\left(R^{2}=94.11\right)$ revealed that parameters under studies significantly affect the biodegradation process $[25,26]$.

In current study there was significance increased $(15 \%)$ in the biodegradation of disperse orange 30 after addition of suitable conc. of different carbon and nitrogen sources (Fig. 7). Like disperse dye-1, nearly $1 \%$ amount of each of source gave maximum biodegradation i.e. $93.32 \pm 1.54 \%$. Higher concentration of nitrogen sources negatively affect the biodegradation process due to nonstability of enzymes responsible for biodegradation.

\section{Study of ligninolytic enzymes during optimization of biodegradation}

The biodegradation of disperse violet 63 and disperse orange 30 depends upon the activity of ligninolytic enzymes which was confirmed by increasing the activity of enzymes with biodegradation [27]. Fungus produces three ligninolytic enzymes which degrade the complex structure of dye by their combined activity. These enzymes are non-specific and has the ability to oxidase complex aromatic compounds like textile dye and render them non-toxic. Maximum ligninolytic activities observed after optimization of various growth factors with RSM were 955.27 $\pm 6.21 \mathrm{UmL}^{-1} \mathrm{~min}^{-1}, 721.15 \pm 3.22 \mathrm{UmL}^{-1} \mathrm{~min}^{-1}$ and 391.45 $\pm 3.26 \mathrm{UmL}^{-1} \mathrm{~min}^{-1}$ for $\mathrm{LiP}, \mathrm{MnP}$ and laccase respectively (Table 1 ). The increased observed after optimizing carbon and nitrogen sources was $78 \mathrm{UmL}^{-1} \mathrm{~min}^{-1}$, $47 \mathrm{UmL}^{-1} \mathrm{~min}^{-1}$ and $87 \mathrm{UmL}^{-1} \mathrm{~min}^{-1}$ for $\mathrm{LiP}, \mathrm{MnP}$ and Laccase (Table 1). These results indicated that all three ligninolytic enzymes actively participated in the biodegradation of aromatic dyes present in the effluents. High activity of LiP compared to other two ligninolytic enzymes indicated its more roles in biodegradation [28, 29].
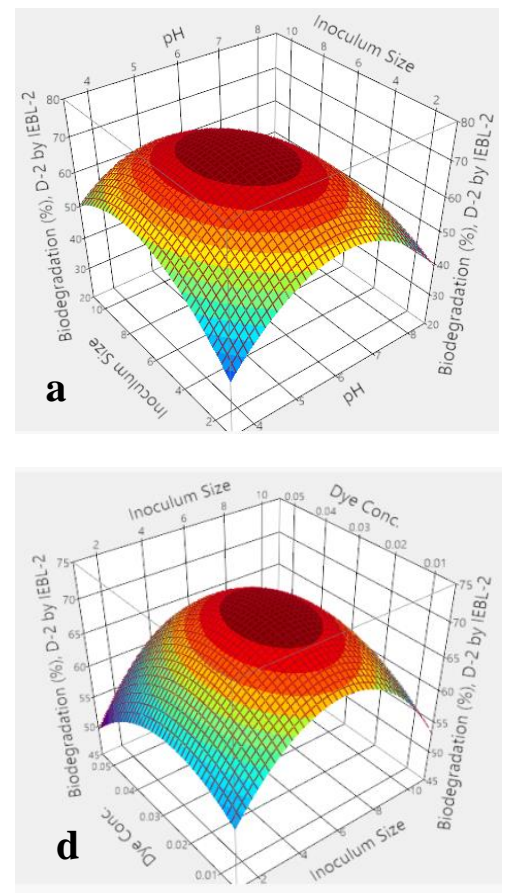
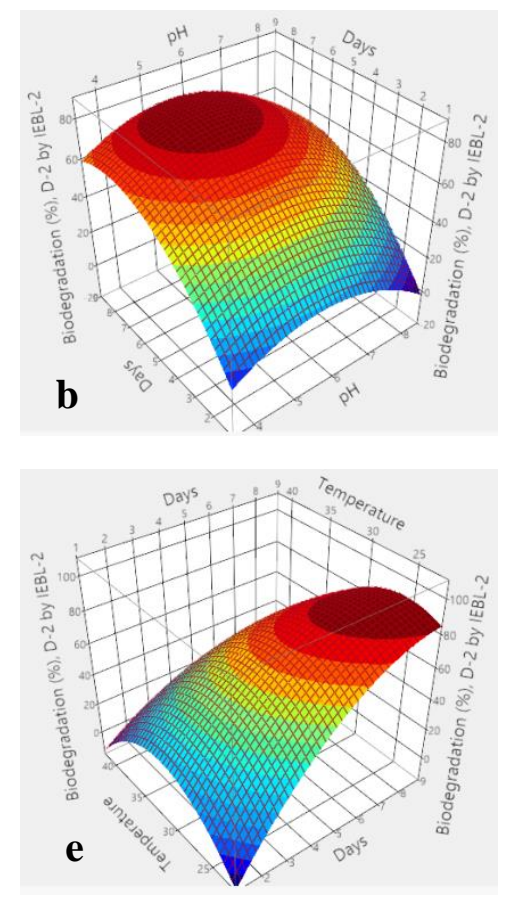
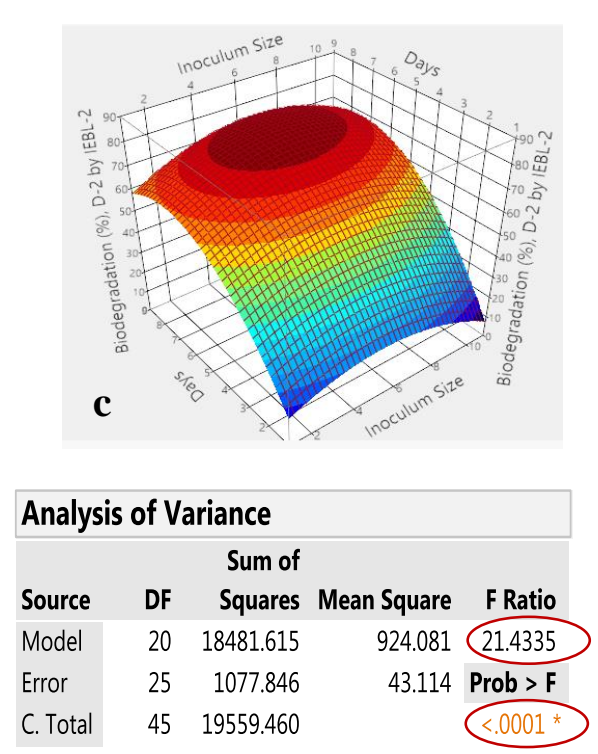

$\mathrm{R}^{2}=94.11 \%$

Figure 6. Response surface 3D graphs showing interaction between various parameters during the biodegradation of disperse orange 30 dye (D-2) by Dadaelea dickinsii IEBL-2, graphs represents positive interaction between (a) inoculum size and $\mathrm{pH}$ (b) days and $\mathrm{pH}$ (c) days and inoculum size (d) inoculum size and dye conc. (e)- day and temperature (e)- statistical analysis of results showing significant effect of parameters on biodegradation. 

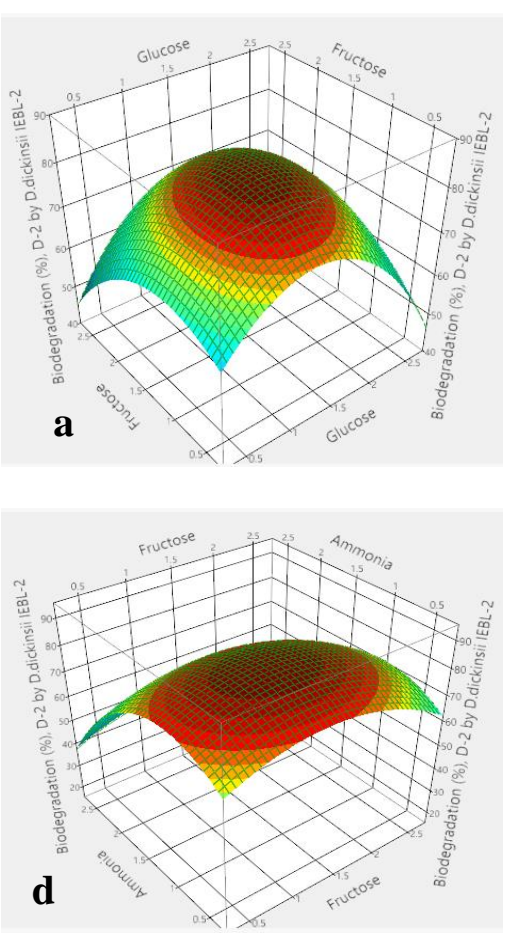
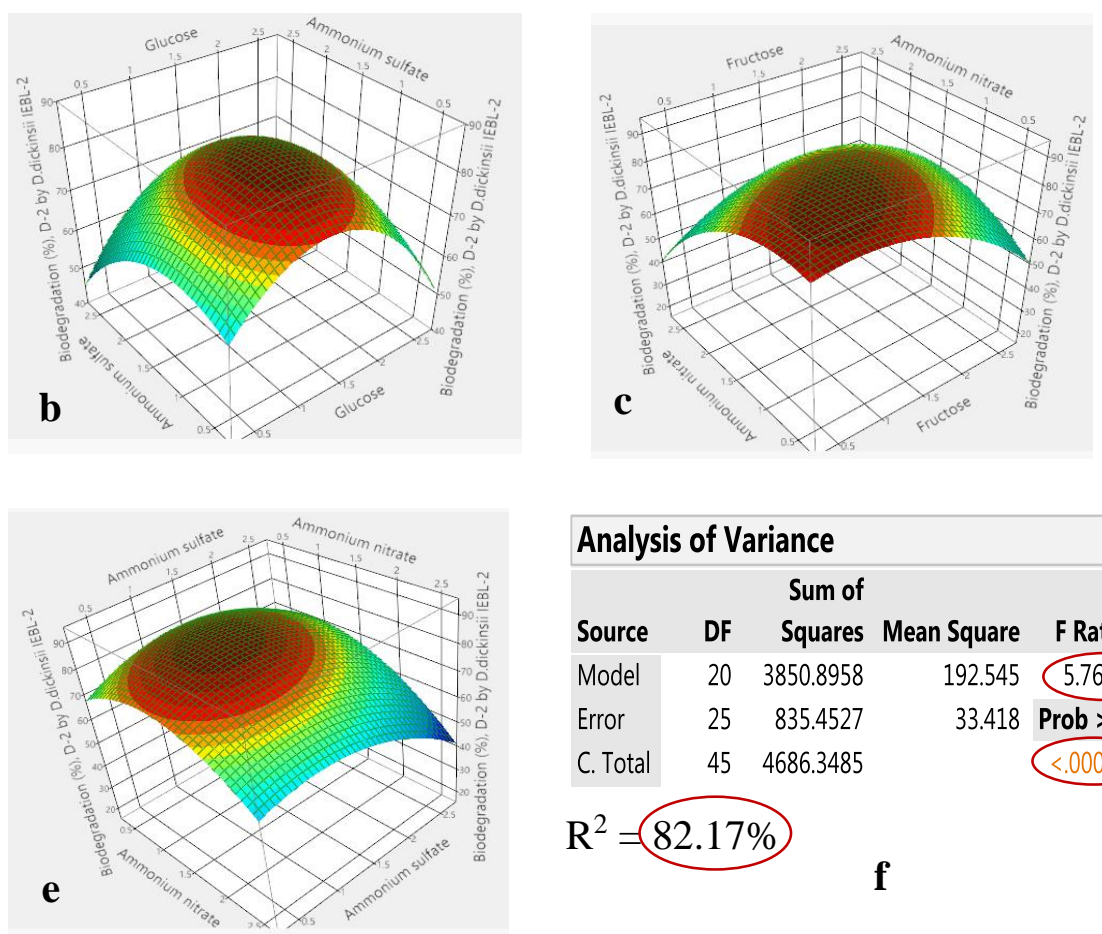

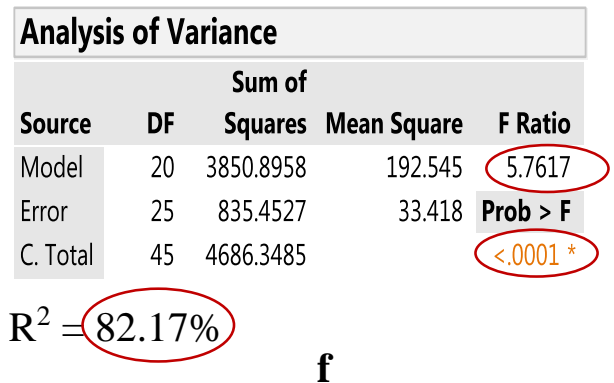

Figure 7. Response surface 3D graphs showing interaction between carbon and nitrogen sources during the biodegradation of disperse orange 30 dye (D-2) by Dadaelea dickinsii IEBL-2, graphs represents positive interaction between (a) glucoase and fructose (b) glucose and ammonium sulfate (c) fructose and ammonium nitrate (d) fructose and ammonia (e)- ammonium sulfate and ammonium nitrate (f)- statistical analysis of results showing significant effect of parameters on biodegradation.

Table 1. Summary of ligninolytic activities during biodegradation process and purification

\begin{tabular}{|c|c|c|c|c|}
\hline \multicolumn{5}{|c|}{ Activities of ligninolytic enzymes by D. dickinsii IEBL-2 (IU/mL/min) } \\
\hline & Step 1 & Step 2 & Step 3 & Step 4 \\
\hline LiP & $955.27 \pm 6.21$ & $1053.9 \pm 4.32$ & $1257.3 \pm 4.53$ & $1487.4 \pm 3.98$ \\
\hline MnP & $721.15 \pm 3.22$ & $768.43 \pm 3.78$ & $989.65 \pm 3.98$ & $1232.2 \pm 3.87$ \\
\hline Laccase & $391.45 \pm 3.26$ & $478.8 \pm 4.09$ & $622.21 \pm 3.01$ & $789.43 \pm 4.32$ \\
\hline
\end{tabular}

Where:

Step 1: After optimization of initial conditions

Step 2: After optimization of carbon and nitrogen sources

Step 3: After ammonium sulfate precipitation

Step 4: After gel filtration chromatography

\section{Purification of ligninolytic enzymes}

Ligninolytic enzymes were partially purified by ammonium sulfate precipitation and gel filtration chromatography in order to enhance their activities and made them more effective for biodegradation. Ammonium sulfate was added in the mixture in different percentage from $20 \%$ to $70 \%$ and activity assay was performed after overnight incubation with pellet. Addition of $60 \%$ ammonium sulfate gave maximum purification of ligninolyitc enzymes from D. dickinsii IEBL-2 due to which activities of ligninolytic enzymes (Table 1) increased compared to activities after optimization of biodegradation [30].

Partially purified ligninolytic enzymes from $D$. dickinsii IEBL-2 were subjected to gel filtration chromatography having column packed with Sephadex G-100. Elutions obtained were used to performed activity assay to monitored purification process. Maximum activities were obtained in elution 12 (LiP), 14 (MnP) and 17 (laccase), as per size of different enzymes (Table 1) [8].

\section{Characterization of ligninolytic enzymes}

Ligninolytic enzymes were characterized to find their optimum $\mathrm{pH}$, temperature and kinetic values $(\mathrm{Km}$ and Vmax). The results showed that $\mathrm{pH} 5.5$ is the most suitable for all three enzymes i.e. LiP, MnP and laccase (Fig. 8). The LiP was found most active enzyme with higher enzymatic activity as compared to other two enzymes. These enzymes showed good activity between $\mathrm{pH} 4$ to 6.5 , after that activity became very low [31]. It was observed that Lip, MnP and laccase gave maximum activities at $28^{\circ} \mathrm{C}$ temperature maintaining during activity assay (Fig. 9). The activity of remain fairly high from temperature $26^{\circ} \mathrm{C}$ to $32^{\circ} \mathrm{C}$ and there was decreased in activity after that [31]. 


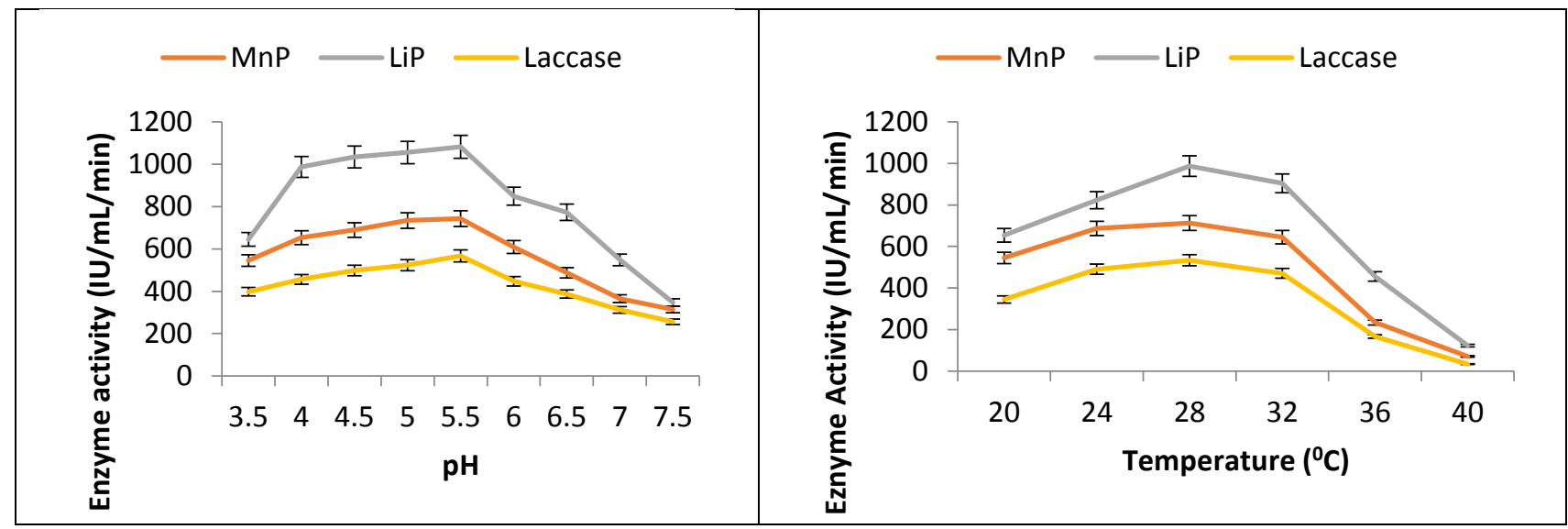

Figure 8. Optimization of $\mathrm{pH}$ for the lignolytic enzymes produced by $D$. dickinsii IEBL-2.

Figure 9. Optimization of temperature for the lignolytic enzymes produced by brown rot fungi during biodegradation process.
The kinetic studies of Lip showed that it has $\mathrm{Km}=0.751 \mathrm{mM}$ and $\mathrm{Vmax}=1250 \mu \mathrm{M} / \mathrm{mL} / \mathrm{min}$ while, $\mathrm{MnP}$ has $\mathrm{Km}=0.700 \mathrm{mM}$ and $\mathrm{V} \max =1000 \mu \mathrm{M} / \mathrm{mL} / \mathrm{min}$ (Fig. 10). The kinetic studies of laccase showed that it has $\mathrm{Km}=0.571 \mathrm{mM}$ and $\mathrm{Vmax}=1428.57 \mu \mathrm{M} / \mathrm{mL} / \mathrm{min}$ (Fig. 10).
Lowered values of $\mathrm{Km}$ indicated the higher affinity of ligninolytic enzymes towards their substrates. Higher values of Vmax indicated the higher rates of enzymes catalyzed reactions under optimized conditions [31, 32].
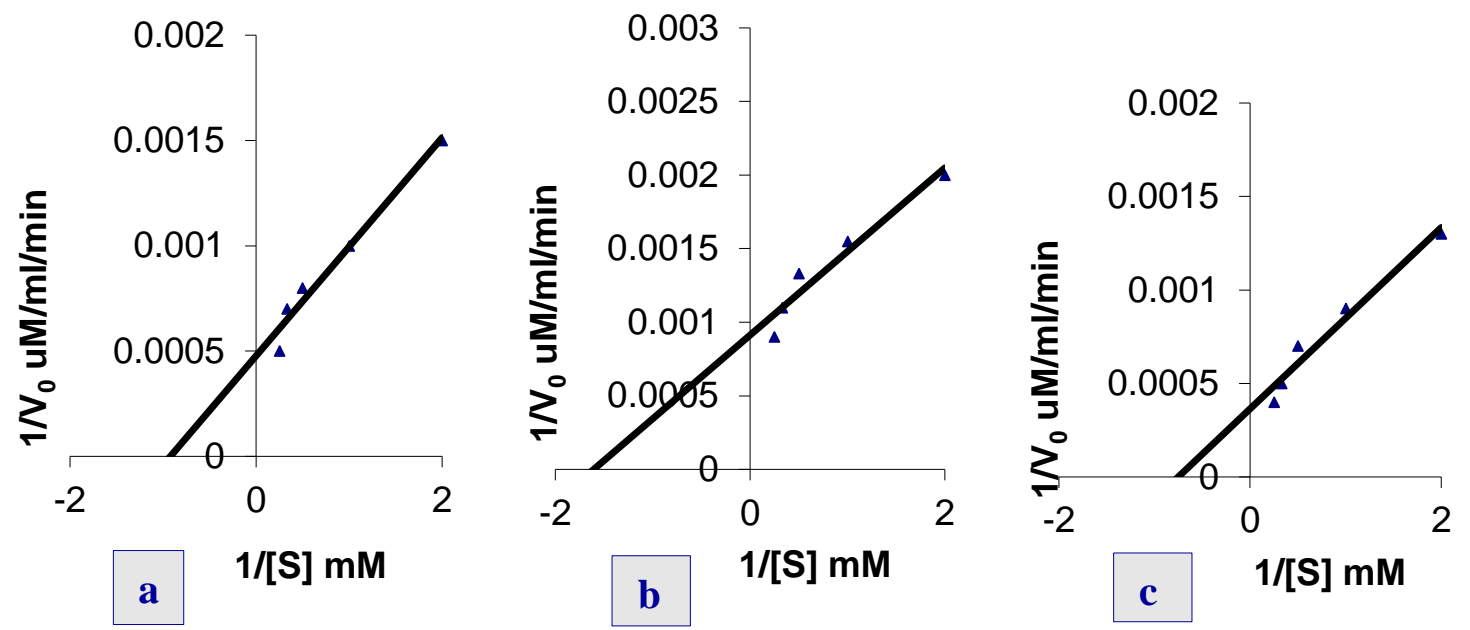

Figure 10. Line-weaver Burk Double Reciprocal plot between $1 / \mathrm{V}_{0}$ and $1 /[\mathrm{S}]$ for (a)- Lignin peroxidase (b)- Manganese peroxidase and (c)- Laccase to determine the values of kinetic parameters i.e. Km and Vmax.

\section{HPLC analysis of dyestuff before and after biodegradation}

The biodegradation process can be monitored by HPLC analysis of untreated and treated samples of textile dyes. Biodegradation of disperse textile dyes usually generated secondary amines, which may be less toxic than dyes or non-toxic. The study of secondary amine as standards with HPLC and comparison of graphs with treated samples would help to detect compounds generated after biodegradation [33]. Three available secondary amines were used as standards i.e. N-Methylaniline, 3.Methyldiphenylamine and Phenylamine. The retention time of $\mathrm{N}$-Methylaniline was $t_{\mathrm{R}}=3.57 \mathrm{~min}$, that of 3-Methyldiphenylamine was $t_{\mathrm{R}}=3.87 \mathrm{~min}$ and Diphenylamine was $t_{\mathrm{R}}=3.69 \mathrm{~min}$ (Fig. 11). Retention time of each compound depends upon its affinity towards column as well as the mobile phase used for elution [27]. 

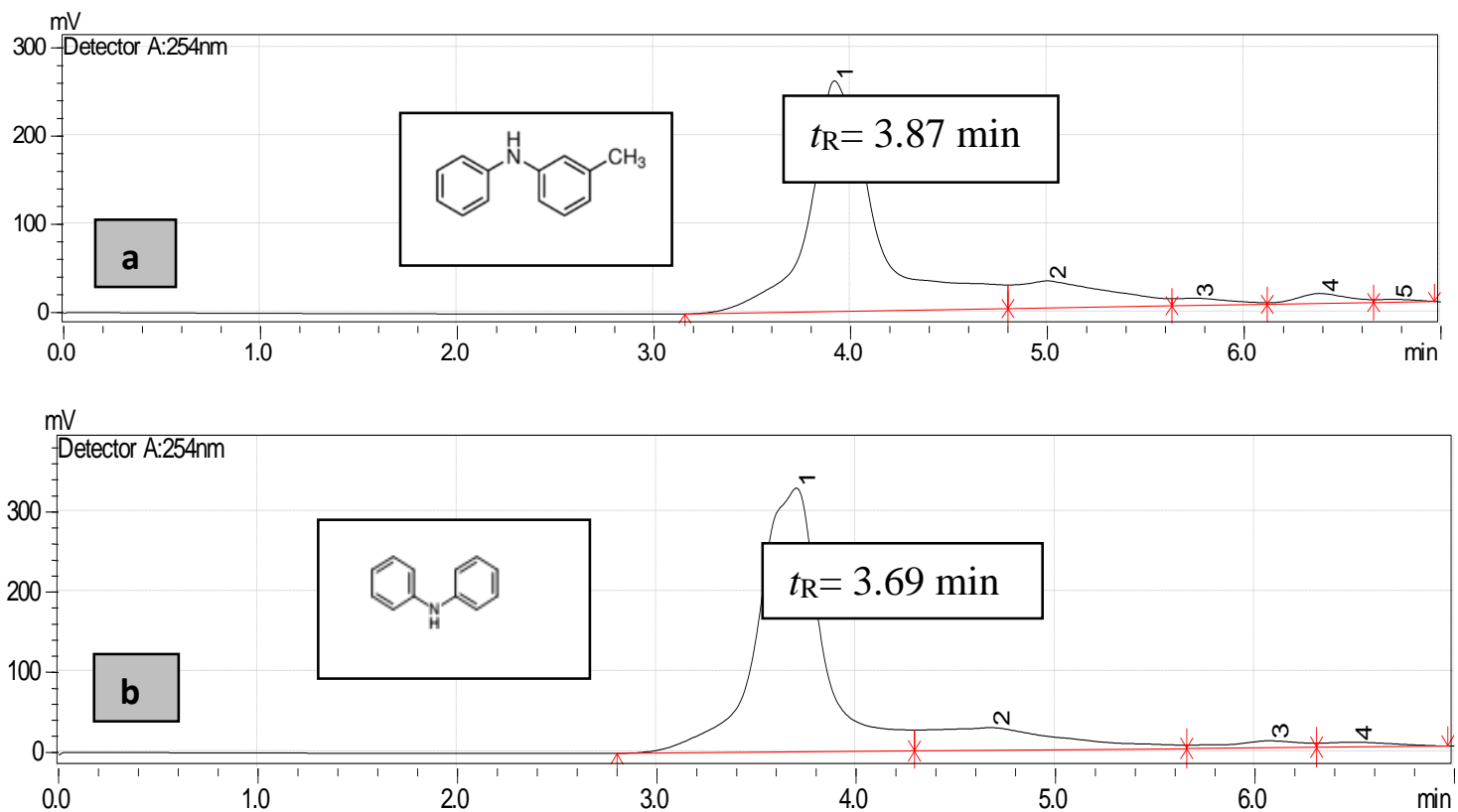

Figure 11. HPLC chromatogram of standard secondary amines (a)- 3-Methyldiphenylamine $\left(t_{\mathrm{R}}=3.87 \mathrm{~min}\right)$ and (b)- Diphenylamine $\left(t_{\mathrm{R}}=3.69 \mathrm{~min}\right)$.

The retention time of untreated disperse dye-1 was $t_{\mathrm{R}}=3.33$ min while its treated sample with $D$. dickinsii IEBL-2 gave two known compounds i.e. 3-methyldiphenylamine and diphenylamine as well as several small peaks of unknown compounds (Fig. 12). The retention time of untreated disperse dye-2 was $t_{\mathrm{R}}=3.29 \mathrm{~min}$ and treated dye-2 with $D$. dickinsii IEBL-2 results into diphenylamine and one unknown compounds (Fig. 13).
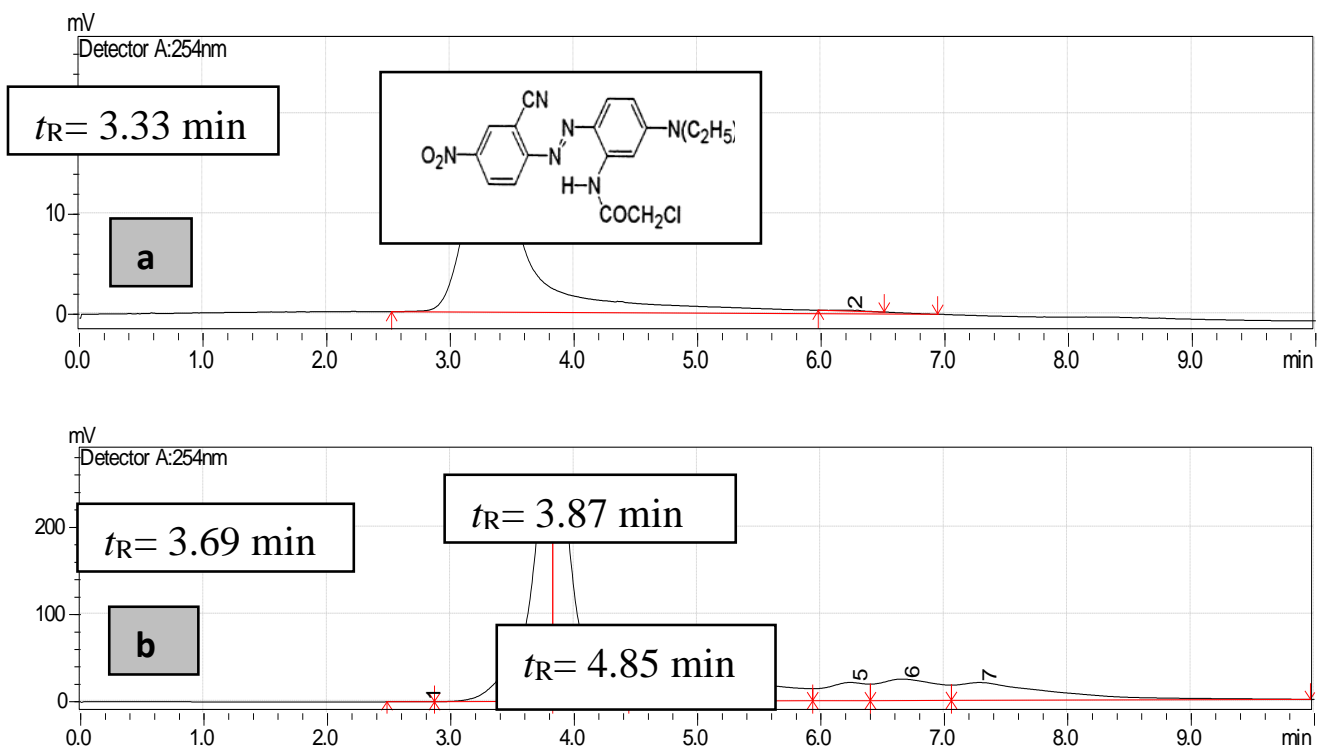

Figure 12. HPLC chromatogram of disperse dye-1 (a)- Untreated sample (b)- treated sample with D. dickinsii IEBL-2, peak 2 for diphenylamine $\left(t_{\mathrm{R}}=3.69 \mathrm{~min}\right)$, peak 3 for 3 -methyldiphenylamine $\left(t_{\mathrm{R}}=3.69 \mathrm{~min}\right)$ and peaks 4-7 are unknown compounds. 

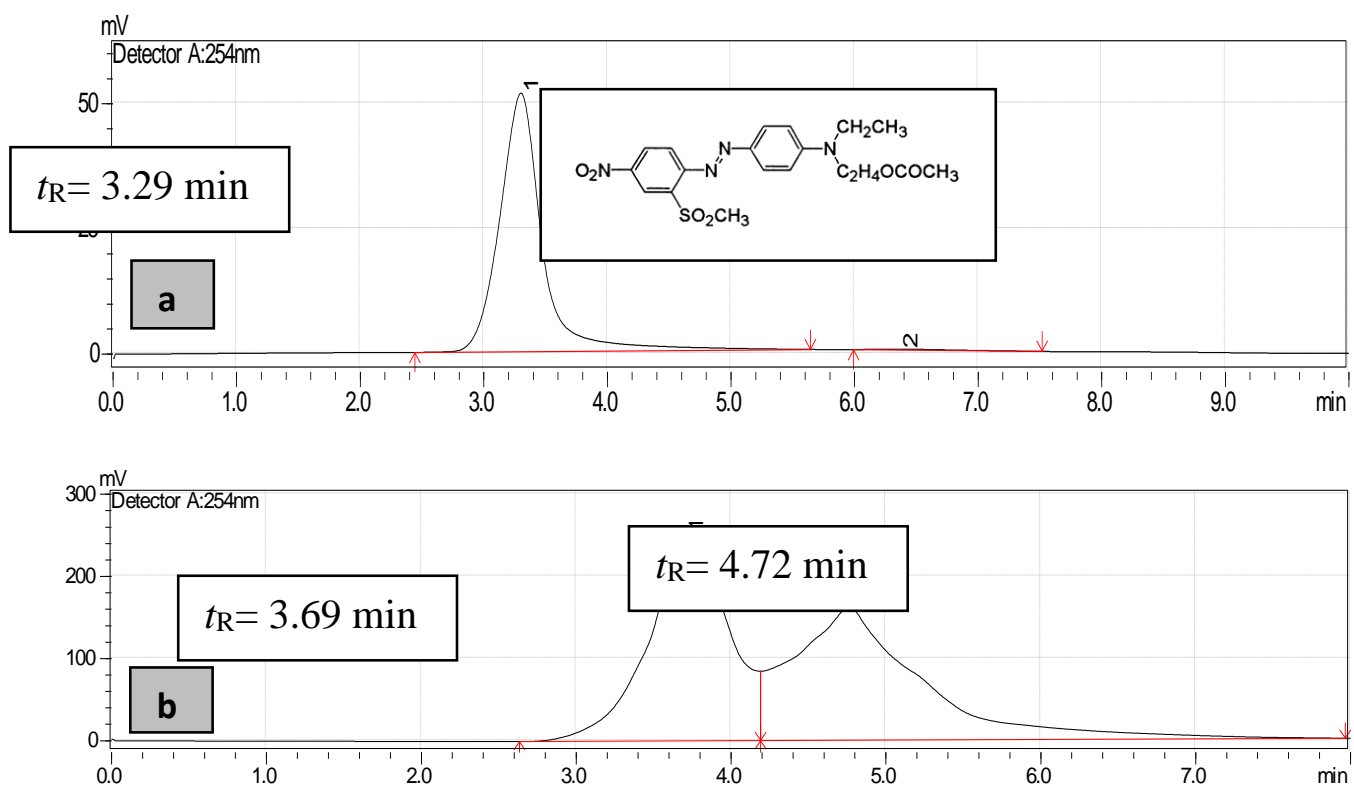

Figure 13. HPLC chromatogram of disperse dye-3 (a)- untreated sample (b)- treated sample with $D$. dickinsii IEBL-2, peak 1 for diphenylamine $\left(t_{\mathrm{R}}=3.69 \mathrm{~min}\right)$ and peak $2\left(t_{\mathrm{R}}=4.72 \mathrm{~min}\right)$ for unknown compound.

The secondary amines produced during the biodegradation of disperse textile dyes under study are less toxic. 3-Methyldiphenylamine may cause small irritation during long exposure but usually it is considered as non-carcinogenic and non-mutagenic. While Diphenylamine reported as non-carcinogenic and non-mutagenic but cause irritation or toxicity during long exposure to organs [34, 35].

\section{Conclusions}

Brown rot fungi is suitable microorganisms with ability of biodegradation of toxic textile dyes in ecofriendly way. $D$. dickinsii IEBL-2 has the potential to degrade disperse dyes more than $85 \%$ by using its ligninolytic enzymes. HPLC analysis confirms the biodegradation and production of less toxic by-products.

\section{Conflict of Interest}

Authors declares no conflict of interest.

\section{References}

1. A. DEMIRCI, M.B. MUTLU, A. GUVEN, E. KORCAN, K. GUVEN, Decolorization of textile azo-metal complex dyes by a halophilic bacterium isolated from Camalti Saltern in Turkey. Clean Soil Air Water, 39(2), 177, 184 (2011).

2. M. ASGHER, Q. YASMEEN, H.M.N. IQBAL, Enhanced decolorization of solar brilliant red 80 textile dye by an indigenous white rot fungus Schizophyllum commune IBL-06. Saud. J. Biol. Sci., 20(4), 347, 352 (2013).
3. S.R. VIJAYALAKSHMIDEVI, K. MUTHUKUMAR, Improved biodegradation of textile dye effluent by coculture. Ecotoxicol. Environ. Safety, 114, 23, 30 (2015).

4. L.S. ROSELIN, R. SELVIN, Photocatalytic treatment and reusability of textile dyeing effluents from cotton dyeing industries. Sci. Adv. Mat., 3, 113, 119 (2011).

5. B. JOSHI, K. KABARIYA, S. NAKRANI, A. KHAN, F.M. PARABIA, H.V. DOSHI, M.C. THAKUR. Biodegradation of turquoise blue dye by Bacillus megaterium isolated from industrial effluent. Amer. J. Environ. Protec., 1(2), 41, 46 (2012).

6. P. VAITHANOMSAT, W. APIWATANAPIWAT, O. PETCHOY, J. CHEDCHANT, Production of ligninolytic enzymes by white-rot fungus Datronia sp. KAPI0039 and their application for reactive dye removal. Internat. J. Chem. Engin., 10, 1155, 66 (2010).

7. R.O. UREK, N.K. PAZARLIOGLU, Production and stimulation of manganese peroxidase by immobilized Phanerochaete chrysosporium. Proc. Biochem., 40, 83, 87 (2005).

8. R.T. MAHMOOD, M.J. ASAD, M. ASGHER, M. GULFRAZ, T. MUKHTAR, M. AKRAM, Study of disperse dyes biodegradation and lignolytic enzymes production potential of indigenous Coniophora puteana IBL-01, a brown rot fungi. Adv. Environ. Biol., 9(11), 139, 150 (2015).

9. R.H. MYERS, D.C. MONTGOMERY, Response surface methodology: process and product optimization using designed experiment. $2^{\text {nd }}$ ed., John Wiley \& Sons, USA (2002).

10. Y.N. KAKASAHEB, V.B. VIJAY, Process optimization by response surface methodology and kinetic modeling for synthesis of methyl oleate biodiesel 
over $\mathrm{H}_{3} \mathrm{PW}_{12} \mathrm{O}_{40}$ anchored montmorillonite $\mathrm{K} 10$. Ind. Eng. Chem. Res., 53 (49), 18690, 18698 (2014).

11. Y. FU, T. VIRARAGHAVAN, Removal of a dye from an aqueous solution by fungus Aspergillus niger. Water Qual. Res. J. Canada, 35(1), 95, 111 (2000).

12. C. SARICOBAN, M.T. YILMAZ, Modelling the effects of processing factors on the changes in colour parameters of cooked meatballs using Response Surface Methodology, World Appl. Sci. J., 9(1), 14, 22 (2010).

13. S.G. JAFARZADEH, M.N. A. RAHMAN, D.A. WAHAB, Optimization of supply chain management based on Response Surface Methodology: a case study of iran khodro, World Appl. Sci. J., 20(4), 620, 627 (2012).

14. F. ZHANG, J.S. KNAPP, K.N. TAPLEY. Decolourisation of cotton bleaching effluent with wood rotting fungus. Water Res., 33(4), 919, 928 (1999).

15. M. TIEN, T.K. KIRK. Lignin degradation enzymes by $P$. chrysosporium: purification, characterization and catalytic properties of unique $\mathrm{H}_{2} \mathrm{O}_{2}$ - requiring oxigenase. Proc. Nat. Acad. Sci., USA, 81, 2280, 2284 (1984).

16. H. WARIISHI, K. VALLI, M. H. GOLD. Manganese (II) oxidation by manganese peroxidase from the basidiomycete Phanerochaete chrysosporium. J. Biol. Chem., 267: 23688, 23695 (1992).

17. B.S. WOLFENDEN, R.L. WILLSON. Radicalcations as reference chromogens in kinetic studies of ono-electron transfer reactions: pulse radiolysis studies of 2, 2'-azinobis-(3-ethylbenzthiazoline-6-sulphonate). J. Chem. Soc. Perkin Trans., 2, 805, 812 (1982).

18. D.I. UDENWOBELE, C.A. NSUDE, A.L. EZUGWU, S.O. O. EZE, C.U. ANYAWU, P.N. UZOEGWU, F.C. CHILAKA. Extraction, partial purification and characterization of pectinases isolated from Aspergillus species cultured in mango peels. Afri. J. Biotechnol., 13(24), 2445, 2454 (2014).

19. Y.P. PAUDEL, C. LIN, Z. SHEN, W. QIN. Characterization of pectin depolymerising exo polygalacturonase by Bacillus sp. HD2 solated from the gut of Apis mellifera L. Microbiol. Disc., 3(1), 2 (2015).

20. L. CELIK, A. OZTURK, M. ABDULLAH. Biodegradation of reactive red 195 azo dye by the bacterium Rhodopseudomonas palustris 51ATA. Afri. J. Microbiol. Res., 6(1), 120, 126 (2012).

21. F. NORDSTRÖM, E. TERRAZAS, U. WELANDER. Decolorization of a mixture of a textile dyes using Bjerkandera spp. Biol. Environ. Tech., 29, 921, 929 (2008).

22. N. SRIRAM, D. REETHA, D. SARANRAJ. Biological degradation of reactive dye effluent contaminated soil, Middle East J. Sci. Res., 17(12), 1695, 1700 (2013).

23. M. SIDDIQUE, A. MAHMMOD, M. SHEIKH, A. GAFOOR, S. KHALIQ, M. BUKHAI, K. YOUSAF,
K. REHMAN, S. ANDLEEB, M. M. NAEEM. A study on the biodegradation of some reactive textile dyes by white rot fungus (Pleurotus ostreatus). World Appl. Sci. J., 18(2), 181, 185 (2012).

24. N.I.K. DHANJAL, B. MITTU, A. CHAUHAN, S. GUPTA. Biodegradation of textile dyes using fungal isolates. J. Env. Sci. Technol., 6(2), 99, 105 (2013).

25. P. KANMANI, R.S. KUMAR, N. YUVARAJ, K.A. PAARI, V. PATTUKUMAR, V. ARU. Microbial decolorization of synthetic dyes and reactive dyes of industrial effluents by using a novel fungus Aspergillus proliferans. Water Environ. Res., 83(11), 2099, 2106 (2011).

26. M.M. HASSAN, M.Z. ALAM, M.N. ANWAR. Biodegradation of textile azo dyes by bacteria isolated from dyeing industry effluent. Int. Res. J. Biol. Sci., 2(8), 27, 31 (2013).

27. H.M.N. IQBAL, M. ASGHER. Characterization and decolorization applicabilicability of xerogel matrix immobilized manganese peroxidase produced from Trametes versicolor IBL-04. Protein Pep. Lett., 20(5), 591, 600 (2013).

28. M. CELEBI, M. ALTIKATOGLU, Z.M. AKDESTE, H. YILDIRIM. Determination of decolorization properties of reactive blue 19 dye using horseradish peroxidase enzyme. Turk. J. Biochem., 38 (2), 200, 206 (2013).

29. H. LADE, S. GOVINDWAR, D. PAUL. Low-cost biodegradation and detoxification of textile azo dye C.I. reactive blue 172 by Providencia rettgeri strain HS11. J. Chem., doi.org/10.1155/2015/894109 (2012).

30. S.P. BANAKAR, B. THIPPESWAMY. Isolation and partial purification of fungal ligninolytic enzymes from the forest soil fungi isolated from Bhadra Wildlife Sanctuary. Front. Biol., 9(4), 291, 299 (2014).

31. S. ASLAM, M. ASGHER. Partial purification and characterization of ligninolytic enzymes produced by Pleurotus ostreatus during solid state fermentation. Afri. J. Biotech., 10 (77), 17875, 17883 (2011).

32. L. WANG, L. ZHIWEI, Z. TENG, L. LING, Z. CHUANQI, L. ZHANXI, S. WANG. Fermentation optimization and characterization of the laccase from Pleurotus ostreatus strain 10969. Enzy. Microb. Technol., 44, 426, 433 (2009).

33. D.S. RAJ, R.J. PRABHA, R. LEENA. Analysis of bacterial degradation of azo dye congo red using HPLC. J. Indust. Poll. Cont., 28(1), 57, 62 (2012).

34. S.M. A.A. SALEH. HPLC determination of four textile dyes and studying their degradation using spectrophotometric technique. M.Sc. Thesis, Faculty of Graduate Studies, Al-Najah National University, Palestine, pp. 33 (2005).

35. H.J. PORWAL, A.V. MANE, S.G. VELHAL. Biodegradation of dairy effluent by using microbial isolates obtained from activated sludge. Water Resour. Indus., 9, 1, 15 (2015). 